\title{
Multinational Firms and the State in Kenya
}

\section{Steven Langdon}

\section{Introduction}

The relationship between multinational firms and the state institutions of less-developed economies is a central question for several reasons. First, many analysts have suggested that the State in less-developed countries plays a major role in shaping the emerging social structure, through state control of much capital accumulation and state manipulation of access to many economic opportunities. 1 The state's relationship with multinational firms is likely to affect how this fundamental social role is played -who gains, who loses, and what the long-term effects of such distribution are on development patterns. Second, many defenders of direct foreign investment have posited a key role for the host-country state in assuring that lessdeveloped nations benefit from the local activities of multinational firms. ${ }^{2}$ Such a position, however, assumes that the host-country state has sufficient independence from such firms to exercise a monitoring or controlling function-and that assumption needs testing.

This article discusses evidence about the Statemultinational relationship in one African country, Kenya, based on research carried out there in 1972-73.3 Kenya, of course, is a particular case, and this means that the analysis cannot automatically be generalised. Kenya was one of the few African countries which experienced settler colonialism; and this may underly certain forms of the State-multinational relationship. Kenya, too, has received most of its postindependence direct foreign investment in import-substitution manufacturing; this distinguishes it from countries like Zambia or Gabon (or even Nigeria) where the concentration has been on resource sector investment; it also differentiates it from others (like Tanzania or Somalia) where relatively little multinational

1 See, for instance, Alavi (1972), Saul (1974), Lamb (1975).

2 See, for instance, Chudson (1973), Reuber (1973).

3 "This research included an interview survey of 81 multinational subsidiaries in Kenya, and a comparative survey of competing lacal enterprises in three industries (soap manufacturing, shoe production and fluorspar mining). In the subsidiary survey, the original sample of 94 firms covered all manufacturing subsidiaries with 50 or more employee, plus most major subsidiaries in commerce, banking, oil distribution, advertising, mineral extraction and transport; some 86 per cent of firms agreed to the interview, though not all of these were prepared to provide all the information requested. Details of the study are reported in Langdon (1976). activity has been concentrated. Nevertheless, the Kenyan example does suggest that some common social processes are at work which are likely to be of relevance to other developing countries as well.

A typical post-independence social process which is evident in Kenya is the widespread emergence of African business interestsinterests that have used their ties with the African political leadership to build up their assets and take on lucrative new activities. ${ }^{4}$ From this amalgam of business interests and political leaders a new social class has gradually developed that can be termed an indigenous bourgeoisie. The relationship of this bourgeoisie to the multinationals is of considerable importance in analysing the dynamics of social structuring in countries like Kenya.

Three ways of analysing this relationship can be identified. One position, that of Warren, suggests that as its accumulation accelerates and its bargaining skill grows, local capital will squeeze foreign capital more and more-and ultimately generate dynamic independent capitalist development in the less-developed country (Warren, 1973). A second position, that of Leys, sees an unstable alliance existing between an 'auxiliary' domestic bourgeoisie and international firms, an alliance with internal contradictions that will sooner or later lead to a breakdown in relations, thereby generating more revolutionary restructuring (Leys, 1975, chapter 8). Third, it is also possible to analyse these relations in terms of dependency theory: Osvaldo Sunkel's model of "transnational integration" (Sunkel, 1973 and 1974). Such a model suggests a more complex intermeshing of foreign and local capital, and thus a much more stable alliance between the two-at the expense of that great majority of poorer citizens in the lessdeveloped country who are not integrated into the relationship. This view would predict neither dynamic independent capitalist development nor imminent breakdown in the periphery country's political economy.

Clearly, which sort of relationship is taking shape is critical in assessing the impact of multinationals in less-developed countries. Warren's

\footnotetext{
4 For details of this emergence see Leys (1975, chapter 5) and Marris and Somerset (1971).
} 
view, for instance, leads one to expect that multinationals' operations will ultimately spark off dynamic development effects, while Sunkel's view leads to a much more negative assessment of the multinationals' impact on peripheral social structures (Sunkel, 1974).

This article examines the role of the State in this ongoing set of relationships first through an illustration of the relations between the State, the multinationals and the local bourgeoisie; then by analysing their implications and considering their economic basis.

\section{MNCs and the State in Kenya: some examples}

Relations between multinational firms and the Kenyan State are complex and intimate. Any detailed study of such relations therefore has to analyse a wide range of instruments and regulations on the state's side, and a myriad of channels of communication and influence on the firms' side. 5 For illustrative purposes, though, one can take representative examples of multinational-state interaction chosen because they illuminate the dynamics of relations among the State, the multinationals and the local bourgeoisie. The five cases outlined here convey reasonably accurately the results of my overall research findings in Kenya, though each case is special in the sense of capturing a particular facet of the relationship.

'The first case involves the soap and shoe multinationals that dominate their respective industries in Kenya. The State has clearly played an important role in the success of these subsidiaries against their international competitors, in that state trade barriers have excluded most competition of this kind. But the State has also been instrumental in securing the success of the multinationals against resident-owned firmsespecially through manipulation of tax impositions. In soap, subsidiaries produce relatively low-bulk, high unit price products (detergents and toilet soap), while local firms produce relatively high-bulk, low unit price products (laundry soap and soap power). The excise tax, as implemented, is levied by weight, and consequently constitutes a much higher percentage of the sale price of local firm products than of subsidiary products. As the National Assembly representative for Mombasa Island noted in the 1966 debate on the tax, low-grade laundry soap sold at Shs. 50/- per 100 pounds, and the tax (of Shs. 0/25 per pound) would therefore increase its price by 50 per cent; while for "twelve

5 These instruments and channels are analysed in consid arable detail in Langdon (1976). dozen tablets of Lux (toilet) soap, which is equivalent to 30 pounds, the selling price is Shs. $87 /-$, but the excise duty is only Shs. 7/50, and the increase is less than 9 per cent" (Kenya Government 1966: 727, 1010 and 1156). The damage done by this tax structure was stressed by local soap manufacturers interviewed in Kenya. However, the government claimed that administrative difficulties made any variation in tax levies by product prices impossible.

In 1972, however, the government extended this tax to shoes, a product which local firms produce at a higher price than the MNC subsidiary, which dominates low unit price output (in plastic sandals for instance). In this case a nondifferentiated tax would clearly hurt the subsidiary and benefit local firms. But administrative difficulties suddenly disappeared. Before implementing the new tax, government asked the multinational subsidiary how it wanted the tax applied and acted accordingly: the result was a differential tax rate with a lower percentage on low unit price shoes, and a higher percentage on higher price shoes. Shoes priced at Shs. 7/50 or below (such as multinational-made sandals) were taxed at Shs. 0/25 per pair, while shoes priced between Shs. 50/- and 75/-were taxed at Shs. 6/- per pair (Kenya Government, 1972).

A second case involves a radio-assembly firm in Kenya. Formerly organised under completely local ownership with a disastrous business record this firm was restructured in 1969. Local Africans and a government parastatal (the Industrial and Commercial Development Corporation-ICDC) took a majority share, but drew in a multinational as a 45 per cent partner. The multinational provided technical training, financing, managerial assistance, intermediate inputs and trade mark rights. The local African businessmen had very close government ties and the government not only provided comprehensive import protection, but also used its ICDC holdings in another large multinational's distributing chain to force that chain to carry the trademarked product, though it had previously carried only a competitive brand. The result was spectacular firm expansion and profitability shared by local Africans and the State through their equity holdings and by the multinational through its dividends, sales of inputs and royalty fees ( 3 per cent of all sales). The multinational was reportedly very pleased with the arrangement because of the excellent contact the local Africans had with the State, and was accordingly accelerating technical training and the transfer of sophisticated products. The local 
Africans were even more pleased with the monopoly rents the multinational trade mark was permitting them to earn.

A third case involves takeover of a local Asianowned tanning extract firm. A group of local Africans and a multinational (which owned Kenya's other tanning extract enterprise) planned to take ownership of the firm. Such takeovers, however, require approval by the Kenya government's Capital Issues Committee, a body based in the Treasury and drawing representatives from other ministries. In the context of this committee's deliberations, debate took place between the multinational and the local partners about the terms of the takeover. The former first insisted on 51 per cent ownership; the latter then countered with a proposal that they take 75 per cent; and the CIC finally used its power to arrange a compromise agreement, giving the multinational a one-third shareholding plus a management contract (and fee) with the new firm.

A fourth case also concerns the shoe industry. A group of African executives from the multinational shoe subsidiary described above recently left (in some anger) to start their own shoe manfacturing enterprise. Conflict with their former employer increased, as the latter was accused of trying to sabotage their machinery orders abroad. Despite this the new firm has been quite successful-unlike the majority of local shoe enterprises. This success rests on the new firm's close state ties. It has received state loans and support as part of the ICDC-organised Nairobi industrial estate; various political figures are among its shareholders; and in the face of subsidiary harassment it was able to ask government officials to intervene in order to organise its machinery imports. In addition, government orders for nurses' shoes stimulated its early business. Similarly, the only clearly successful local soap firm competing with the subsidiaries was half-owned by a senior civil servant, and had received important soap orders from the Ministry of Works.

Finally, a fifth case also revolves around the multinational shoe subsidiary. A local firm sought to win the right to supply it with eyelets, for its shoes, which had previously been imported. The subsidiary resisted, however, and conflict became bitter, with the local firm gaining support from the then Minister of Commerce and Industry. Finally, however, President Kenyatta is said to have intervened personally, declaring that the shoe subsidiary was "our friend", and forcing all parties to attend a large meeting where the issue was successfully resolved, the subsidiary having the final decision in the matter.

Each of these cases is, of course, unique. But they also represent certain broad tendencies evident in Kenya. And such tendencies-perhaps contradictory, yet perhaps ultimately consistent -justify some theoretical speculation: this is offered in the next section.

\section{Implications and speculations}

The above cases may appear contradictory. The State sometimes helps to structure the economy in favour of subsidiaries and against local enterprise; but it also sometimes helps local enterprise against the multinationals. One explanation could simply be that the State has many arms, and some respond to certain pressures, while others respond to the influence of opposing groups; but such a pluralist notion, while undoubtedly reflecting some real divisions among state institutions, nevertheless provides too easy and simplistic an answer. There is a more sophisticated consistency to these patterns of political economy.

Certainly one finding is evident from all these cases: the key role of the State in shaping economic relationships within Kenya. Much of the material from my field research suggests that, as in the first and second cases above, this role is usually exercised in co-operation with, and to the benefit of, the multinational sector in Kenya. As the cases show, however, the State clearly maintains some independence in this relationship with the multinationals. There seems, in fact, to be a mutually dependent symbiosis at work. The modern Kenyan State clearly has some sophisticated economic instruments to use (differential taxes, widesread shareholdings, etc.), and the multinationals seem to rely, to a degree, on such manipulation for their surplus appropriation within Kenya.

It seems clear, however, from the fourth case especially, that the Kenyan State is also prepared to play its regulative, protective role on behalf of the local bourgeoisie, even when certain subsidiaries may be threatened. There is a local bourgeoisie emerging in Kenya-and it too has an intimate relationship with the State. That relationship, as the second and third cases imply, however, is being increasingly meshed with the State-multinational relationship in even more complex forms of symbiosis. Again, the Kenyan State has sophisticated instruments with broad discretionary powers (particularly the CIC) that 
permit it to organise and enforce such intermeshing.

It would, of course, be possible like Warren (1973) to regard such developments as evidence that the domestic bourgeoisie is eager and able to squeeze foreign capital. In the same way, the fourth case might be said to illustrate Leys' (1975) prediction of emerging conflict between foreign and 'auxiliary' capital. Overall, though, the combination of these first four cases could illustrate a careful State-sponsored process of intermeshing and organising multinational-local bourgeois relations in such a way as to develop a stable, longterm symbiosis at the top of the Kenyan political economy. The fifth case, with its evidence of State willingness to intervene to defuse conflict, would seem to justify this perspective. Foreign capital is not forced to sacrifice surplus appropriation as part of the symbiosis-as the generous terms in case 2 and the management contract provisions in case 3 illustrate. But the State is successfully shuffling prominent Africans into the dominant regulated economy-as multinational partners, executives, and even competitors.

The multinationals' willingness to co-operate in this process is not that surprising in the context of case 5. In the end, the multinational sector seems able to count on the State playing an overriding role in the political economy, managing the mechanics of symbiosis should they threaten to get out of hand, and thereby defending the long-term role of multinationals in Kenya. It is this that undercuts Warren's perspective: it is not an independent bourgeoisie which is emerging in Kenya and itself manipulating the State apparatus. Rather the State's symbiosis with the multinational sector gives it an institutional independence vis-a-vis that emerging local bourgeoisie, while at the same time the latter remains heavily dependent on the State for its surplus appropriation. This makes it possible for the Kenyan State to enforce the over-riding Kenyan symbiosis with foreign capital, disciplining local businessmen who move too strongly against multinational interests. Such an over-riding state role as conflict regulator also questions the likelihood that the contradictions pointed out by Leys could emerge significantly. The auxiliary bourgeoisie remains too state-dependent to extend opposition to multinational enterprise of a kind that would create serious instabilities, while the strength of the State also guarantees that this bourgeoisie can retain a rising share in the profits of MNC subsidiaries over time.

The implication of all five cases taken together, then, may simply be that the Kenyan State plays a subtle and sophisticated role rather well; that role is to regulate, extend and defend a growing multinational-State-domestic bourgeoisie symbiosis in the country.

What is the economic and social basis of this symbiosis? Why are the multinationals able to carve out so prominent a role for themselves? And why does the Kenyan State play the role it seems to? Answers could be suggested at many levels of analysis; but two deserve emphasis in the present context.

At the level of straightforward economics of industrialisation, reliance on multinationals in Kenya has resulted in high rates of profitability in Kenyan manufacturing. Subsidiaries have transferred technology from abroad in the form of differentiated, trade marked products and of fairly sophisticated processes to manufacture these; and this kind of technology transfer, especially with the State helping to offset foreign and local competition, lends itself to the accumulation of high profit, or 'monopoly rents' based on the technology and trade marks. In the 29 Kenyan manufacturing subsidiaries from which profit details were obtained in $1972 / 73$, the after tax rates of return reached 21 per cent of capital employed (compared to overall rates in the parent firms of 9 per cent after tax). Such high profitability is a powerful incentive to the State and the local bourgeoisie to co-operate with the multinationals -in so far as those profits can be shared through the intermeshing described above. Similarly the multinationals appear to rely on local co-operation to maximise the long-run and secure profitability of technology transfer through their subsidiaries to the peripheral economy. Technology transfer and the local surplus appropriation it permits are, in short, the main focus of localmultinational bargaining. Their control of technological innovation on a world scale, plus the efficiency of the head-office-to-subsidiary channels of technology transfer, ${ }^{6}$ are the key levers which give the multinationals such bargaining strength in Kenya, as in other less developed countries.

There is also a second, deeper level at which this transfer of technology by multinationals provides the basis for symbiosis. Multinational technology transfer has shaped the wider process of class formation and income determination in Kenya in such a way as to facilitate and sustain a highly unequal socio-political structure. At the same time, the income distribution associated with this

\footnotetext{
6 On concentrated multinational control of the research and development process see Kaplinsky (1974); on the greater efficiency of subsidiary technology transfer channels see Baldwin (1970).
} 
structure has provided the market required for the multinationals' transfer of their consumption technology (an egalitarian income distribution would generate little demand for private automoblies where per capita income is $£ 100$ per year!). Sharing in subsidiary profits, of course, financially strengthens the emerging bourgeoisie. But the multinationals' socio-political impact goes much further than this. Multinational profits and taxes raise State revenues-which can be used to defuse periodic political protest through minimal gestures (like eliminating lower-level school fees in Kenya). More important, Kenyan evidence suggests that the highly-mechanised nature of multinational production technology helps to generate a small, relatively well-paid labour aristocracy in the country, making working-class political protest less likely. ${ }^{7}$ At the same time, as noted above, the multinationals' growing role weakens the emergence of independent industrialists in the system, pushing local entrepreneurs who do succeed into close relations with the State and/or the subsidiaries; this too weakens the chances of independent political opposition to the existing structures.

This whole process, in fact, looks very much like the pattern of "transnational integration" that Sunkel discusses: a segment of Kenyan society is being integrated more fully into transnational capitalist production through multinational technology transfer, while most Kenyans remain excluded from the benefits of the transfer. The integration of that minority into the transnational system, though, serves to perpetuate the existing socio-political structure, through the benefits the minority clearly does enjoy.

\section{Conclusion}

This examination of State-multinational relations in one country reveals a close symbiosis among the State, multinationals and the emerging local bourgeoisie-with the process of multinational transfer of new product and production technology at its heart. It has also indicated, however, the important role of the State in organising and stabilising the mechanics of this symbiosis in Kenya. It is in the light of this rather effective state role that Sunkel's analysis of the likely relations between the multinationals and the local bourgeoisie appears more astute than that of Warren or Leys. The State seems to be critical in enforcing the symbiosis through which politically threatening conflicts between foreign and local

7 See the arguments and evidence in Arrighi (1970) and Amsdon (1971). capital are avoided in Kenya, and through which transnational integration is promoted.

Such a conclusion should reinforce scepticism about the role of multinationals in less developed countries. The pattern of multinational-State relations in Kenya clearly casts doubt on the view that the local State will control the multinationals on behalf of poor local majorities. Bargaining is undertaken on behalf of rich local minorities, and in a context of close State-multinational intermeshing of interest. Anew, more enduring dependency is being shaped for Kenya, based around this relationship between multinationals and the State, and with consequences of continuing poverty for the great bulk of Kenyans.

\section{References}

Alavi, H., 1972, 'The State in Post-colonial Societies-Pakistan and Bangladesh', New Left Review 74

Amsden, A., 1971, International Firms and Labour in Kenya, 1945-1970, London, Cass

Arrighi, G., 1970, 'International Corporations, Labour Aristocracies, and Economic Development in Tropical Africa', in R. I. Rhodes (ed.), Imperialism and Underdevelopment, Monthly Review Press 1970 New York

Baldwin, R. E., 1970, 'International Trade in Inputs and Outputs', American Economic Review $60: 2$

Chudson, W., 1973, 'Africa and the Multinational Enterprise', in H. R. Hahlo et al (eds.), Nationalism and the Multinational Enterprise, Dobbs Ferry, New York

Kaplinsky, R., 1974, 'Technology for Development', Scienza e Technica, April

Kenya Government, 1966, National Assembly, House of Representatives, Official Report vol. XI Part I, Nairobi

Kenya Government, 1972, 'The Consumption Tax Act', Kenya Gazette Supplement, Acts 1972, Nairobi

Langdon, S. W., 1976, 'Multinational Corporations in the Political Economy of Kenya', D. Phil. thesis, Sussex

Lamb, Geoff, 1975, 'Marxism, Access and the State', Development and Change, VI : 2 April

Leys, C., 1975, Underdevelopment in Kenya, Heinemann, London 
Marris, P. and A. Somerset, 1971, African Businessmen, Routledge and Kegan Paul, London

Reuber, G. L., 1973, Private Foreign Investment in Development, OUP, London

Saul, John, 1974, 'The State in Post-Colonial Societies-Tanzania', Socialist Register

Sunkel, Osvaldo, 1973, 'Transnational Capitalism and National Disintegration in Latin America', Social and Economic Studies, 22 : 1
Sunkel, Osvaldo, 1974, 'External Economic Relationships and the Process of Development: Suggestions for an Alternative Analytical Framework', in R. B. Williamson et al, Latin American-US Economic Interactions, American Enterprise Institution for Public Policy Research 1974 Washington

Warren, B., 1973, 'Imperialism and Capitalist Industrialisation', New Left Review, 81 